Revue Française de Civilisation Britannique

XXI-2 | 2016

Economic Crisis in the United Kingdom Today: Causes and Consequences

\title{
Some "Heterodox" Explanations of the Economic Crisis
}

Quelques analyses "hétérodoxes" de la crise économique

Nicholas Sowels

\section{CpenEdition}

Journals

Electronic version

URL: http://journals.openedition.org/rfcb/1097

DOI: $10.4000 /$ rfcb. 1097

ISSN: 2429-4373

Publisher

CRECIB - Centre de recherche et d'études en civilisation britannique

Electronic reference

Nicholas Sowels, "Some "Heterodox" Explanations of the Economic Crisis », Revue Française de Civilisation Britannique [Online], XXI-2 | 2016, Online since 05 October 2016, connection on 30 April 2019. URL : http://journals.openedition.org/rfcb/1097 ; DOI : 10.4000/rfcb.1097

This text was automatically generated on 30 April 2019.

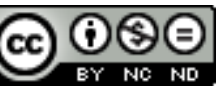

Revue française de civilisation britannique est mis à disposition selon les termes de la licence Creative Commons Attribution - Pas d'Utilisation Commerciale - Pas de Modification 4.0 International. 


\title{
Some "Heterodox" Explanations of the Economic Crisis
}

\author{
Quelques analyses "hétérodoxes" de la crise économique
}

\author{
Nicholas Sowels
}

\section{Introduction}

1 Nine years after the public rescue of Northern Rock and eight years after the bankruptcy of Lehman Brothers, the global economy is still dealing with the repercussions of the 2007-2008 financial crisis and the ensuing Great Recession. At the time of writing, the world growth is still weak. The same holds true for the United Kingdom, as the relatively better growth between the second half of 2013 and the first half of 2015 gave way to slower growth at the end of 2015. With the Brexit vote on 23 June 2016, the growth outlook has further deteriorated. One very clear indicator of the continued clouded global outlook is the cost of money, as interest rates in the UK and elsewhere have been stuck at the "lower bound" (i.e. near 0\%) since the crisis. In fact, the Bank of England even lowered the bank rate to $0.25 \%$ in August 2016, in anticipation of a Brexit-induced recession.

2 There is thus a good case to make that the world economy is still experiencing the effects of the last crisis, and that neoliberal capitalism is undergoing the kind of profound crisis that affected the Keynesian/Fordist capitalist regime during the 1970s. The Brexit vote and Theresa May's pledge on entering Downing Street - "to make Britain a country that works for everyone" - indicate dramatically the strains on British society resulting from the crisis. Yet the Brexit process itself will almost surely worsen Britain's economic performance for quite some time.

3 This article argues that a continuation of neoliberal policies, which became quite neoThatcherite in the Conservative Party election manifesto in May 2015, could well perpetuate economic stagnation, given the deepening contradictions of neoliberalism as an economic, political and social system. Section 1 starts by noting that the 2007-2008 
financial crisis was not an accident, but a result of financial sector liberalisation. It also provides a brief overview of the main consequences of the crisis in the United Kingdom. The following section examines to what extent the present macroeconomic policy tools have run their course and are no longer capable of generating more than unbalanced and unsustainable growth. Section 3 then puts forward some heterodox and Marxist explanations of the present state of capitalism. The article concentrates on the specific situation of the UK, though much of the analysis goes beyond the British economy, especially in the United States.

\section{A financial crisis waiting to happen}

4 The financial crisis following the collapse of Lehman Brothers on $15^{\text {th }}$ September 2008 apparently caught policy-makers and commentators unaware, or so at least many claimed. Martin Wolf, chief economics commentator of The Financial Times, was one of them. In The Shifts and Shocks: What We've Learned - and have still to learn - from the financial crisis, published in 2014, he clearly admits that he had not foreseen such a general breakdown of finance, and states unambiguously that conventional economics had got it wrong. ${ }^{1}$

Yet the writing had very much been on the wall for a long time, even if the US subprime mortgage crisis was somewhat unexpected. During the first half of the 2000s, the financial press and policy-making community had long been warning about "imbalances" in the world economy, notably the huge US current account deficit. At the annual conference of central bankers and monetary policy specialists in Jackson Hole (Wyoming) in August 2005, Raghuram Rajan - chief economist at the IMF and then Governor of the Reserve Bank of India - very specifically cautioned that the global banking system was massively over-stretched and over-exposed to risk. His arguments however were roundly criticised by his audience. ${ }^{2}$ Even Alan Greenspan (Chairman of the US Federal Reserve from August 1987 to January 2006) had on several occasions in 2003 and 2004 mentioned in official speeches that there were problems in the US housing market. ${ }^{3}$ But such doubts were generally pushed aside in a kind of group-think which, in the words of Nobel laureate Joseph Stiglitz, meant that "no one challenging the prevailing view would be treated as credible $" .4$

6 In fact, over the years, Fed policy had evolved into "cleaning" not "leaning". In the previous two decades, the Fed had dealt reasonably successfully with successive financial crises: the stock market crash in October 1987, the Mexican crisis in 1994, the Asian crisis in 1997, the combined Russian and LTMC crises in 1998, as well as the major high-tech stock collapse in 2000, followed by falls in conventional stocks in the wake of the $9 / 11$ attacks (in 2001). These experiences had led the Fed to develop a policy of not intervening to dampen asset market bubbles (of not leaning against asset price rises), but instead of providing support for markets after crashes (cleaning up). As time went by, this strategy encouraged moral hazard in the markets: it even became widely-known as the "Greenspan put": i.e. investors knew that they could always sell assets at a good price because Alan Greenspan would bail out markets with cheap money in the wake of crashes.

7 For the UK, the financial crisis began spectacularly with the collapse of Northern Rock in September 2007. The bank's story is a textbook case of the perils of financial market deregulation. Previously a building society, Northern Rock had "demutualised" and become a bank in the 1990s, as did many other building societies. Subsequently, the 
bank's management pursued an ambitious development strategy, based increasingly on borrowing funds in the international capital markets to provide mortgages in the UK. These in turn were sold back into the markets as mortgage-backed securities (MBSs). Its expansionary strategy became also heavily dependent on short-term borrowing in the interbank markets. So when demand for MBSs by international investors began to slow in the summer of 2007, Northern Rock found itself facing increasing problems in borrowing to finance its operations. As a result, it turned to the Bank of England for liquidity support in September 2007. This in turn led to panic by individual depositors, and Britain's first bank run in 150 years, as savers withdrew their funds. The UK government had to step in, first to support the bank and then to nationalise it in February 2008. The fate of the bank was precisely an example of the dangers Rajan had warned about in 2005.

During 2007 and 2008, numerous other financial institutions experienced failure or near bankruptcy. ${ }^{5}$ But the global crisis was only fully triggered when Lehman Brothers collapsed in September 2008, and global financial markets seized up. In the UK, this lead rapidly to the near closure of RBS, the Lloyds Banking Group and Bradford \& Bingley. To prevent this, these banks were nationalised by the Labour Government, in its successful attempt to stop the UK banking system from breaking down completely. Significantly, these forced nationalisations did not lead to any profound change in the operations of the banks. The banks' ownership was transferred to UK Financial Investments Ltd. (UKFI), a company operating under private law, though wholly owned by HM Treasury. UKFI has largely functioned as an arm's length institution, with the remit of preparing the banks for return to the private sector. ${ }^{6}$ At the time of writing, this process is in its advanced stages: Northern Rock was sold to Virgin Money in 2012; and a significant share of the Treasury's stake in the Lloyds Bank Group has been returned to the private sector. Finally, in August 2015, the government began selling its shares in the Royal Bank of Scotland (RBS) group, albeit at a loss.

\section{The authorities' response to the crisis}

9 In short, the response of the UK authorities - in line with authorities throughout the industrialised world - was to pursue a policy of getting back to business as usual... as quickly as possible. Successive governments' reactions to this fundamental failure of financial capitalism - when the "commanding heights" of the economy were no longer able to function alone - have been largely limited to re-regulation, which we shall examine in the next section.

In terms of the overall economy, the financial crisis and Great Recession have had a profound impact. After contracting sharply in late 2008 and 2009, output only really began growing again in mid-2013, after years of "flat-lining" as growth remained very weak (see the Table at the end of the article). This was accompanied by a rise in unemployment, which was in fact considerably more modest than in other major industrialised economies! Indeed, the headline unemployment rate in the UK began to recede quite quickly, while the number of people in work rose to over 30 million by the end of 2013, ${ }^{7}$ testimony to the greater flexibility of the British labour market. But such flexibility has not come without cost. Firstly, wages have only recently started to rise again, so that on the whole household incomes stagnated between 2007 and 2014. Secondly, the flexibility in the UK labour market has been achieved at the expense of 
greater employment insecurity: for example, in May-July 2015, 1.68 million people were employed on a temporary basis. ${ }^{8}$

11 This labour market picture is also directly connected with the stagnation of labour productivity since the onset of the crisis: in the $2^{\text {nd }}$ quarter 2015, output per hour worked was just $0.4 \%$ higher than it had been seven years earlier. The poor productivity performance of the UK - especially in manufacturing industry - is furthermore being accompanied by a perennial, structural problem faced by the UK economy, namely the persistence of large current account deficits. These have actually opened up since the onset of the Great Recession, so that by the mid-2010s the annual deficit was running at over 5\% of GDP (see Table). Such high deficits stem partly from Britain's poor competitiveness and weak trade balance. But they also stem from recent declines in its income earnings from overseas investments, which are not fully explained at present.

The authorities (successive governments and the Bank of England) responded to the crisis in three broad ways which are discussed in this section: firstly, by using fiscal policy to hold up demand before switching to a policy of "austerity" as of 2010; secondly by pursuing very expansionary and unconventional monetary policy; and thirdly by supporting and then regulating the banking system.

First, as we have already seen above, the Labour government of Gordon Brown reluctantly - but rightly - did what was necessary to stop the UK banking system from collapsing. In doing so, the UK authorities participated in wider international actions to prevent the financial crisis from triggering a slump as occurred in the 1930s. Whatever may be said about the failings of policy-makers before the crisis, and subsequently, a far greater economic collapse and a breakdown of the international economic system were prevented by strong, pro-active policies by public authorities across the globe. In short, as the American academic Daniel Drezner argues, The System Worked. ${ }^{9}$ Globally, this involved the world's authorities committing approximately $\$ 14$ trillion dollars in direct injections into banks' capital, guarantees, lending and other measures: the major share being guarantees and short-term lending..$^{10}$ In the UK, the National Audit Office states that $£ 1.2$ trillion was provided in support at the height of the crisis, though "only" $£ 133$ billion involved direct cash outlays, while $£ 1,029$ was committed in guarantees that were not finally mobilised. As of March 2015, these outstanding government guarantees had fallen to $£ 22$ billion, but cash outlays remained significantly higher at $£ 93$ billion. ${ }^{11}$ On top of this, the Labour government pursued a number of direct measures to support economic activity, such as cutting VAT to $15 \%$ for a year in 2009 , and bringing forward $£ 3$ billion in capital spending. ${ }^{12}$

These spending commitments led to a sharp deterioration in public finances, which was also substantially compounded by the fall in tax receipts (see Table). As two renowned American economists, Carmen Reinhart and Kenneth Rogoff, pointed out in 2009, compared to normal economic downturns, financial crises tend to be far longer and also lead to greater budget deficits due to falling tax revenues. ${ }^{13}$ Their subsequent research, based once again on cross-country statistical comparisons over time, has also suggested that once the public sector debt to GDP ratio rises above $90 \%$, it is accompanied - on average - by a fall in growth of 1 percentage point. ${ }^{14}$ This, easy-to-understand finding was published in 2010 and had a strong impact on policy-makers in Europe especially. Although it is a statistical average, whose data and conclusions were subsequently challenged, the message to governments, including the UK government was clear: with public sector debt levels approaching $90 \%$ of GDP it was important to do something. There 
were also very strong pressures from financial markets which were forcing up interest rates markedly on new government borrowing in countries deemed to be risky, like Italy, Spain, Portugal and Greece. These factors led to a switch to trying to control public finances in Europe.

In Britain, the change in policy occurred perhaps more clearly than elsewhere as the Conservative-Liberal Democrat Coalition government entered office in May 2010, and immediately embarked on a publicly-declared programme of spending cuts. At the time, its stated objective was to close the $10 \%$ deficit during the course of the Parliament. This policy was controversial and itself contributed to the flat-lining of the economy subsequently. In the event, the coalition government "only" halved the deficit, although George Osborne's public discourse was very much austerity-centred, even referring to Mrs Thatcher's "not for turning" squeeze on public spending in the face of a deep recession and virulent criticism in the early 1980s. In practice, the coalition's stated goal was too hard to achieve, and policy was more pragmatic. The ongoing pressure on public finances, however, explains the renewed austerity drive after the May 2015 elections, with Mr Osborne pledging to close the deficit gap by 2019 in the June budget. Following the Brexit vote, the new Conservative government led by Theresa May has indicated that it will not be possible to achieve budget surpluses before 2020 .

Given the drive to fiscal consolidation since 2010, the task of stimulating growth has largely fallen on monetary policy. The result has been a historically-unprecedented monetary stimulus. This helped avoid the worst in the immediate aftermath of the crisis, but its longer term consequences seem less clear. The Bank of England followed all central banks in cutting interest rates to the "lower-bound", when the (short term) bank rate was brought down to $0.5 \%$ in March 2009. ${ }^{15}$ At the same time, the Bank embarked on its programme of "quantitative easing" (QE), namely the purchase of government bonds, with the aim of raising their prices in the market and hence reducing their rates of return. ${ }^{16}$ By doing this, the Bank of England and other central banks seek to bring down long term interest rates in the market, while also injecting liquidity into banks. In turn, it is hoped that these direct results of $\mathrm{QE}$ encourage bank lending to companies and individuals. It is generally believed that the $\mathrm{QE}$ in the early days of the crisis and the Great Recession did help stabilise the financial system and so contribute to economic stability more widely. But as time went on, the ambiguities of policy seemed stronger. These were clearly summarised, for example, by John Kay, a leading UK economist and regular contributor to The Financial Times, who in July 2013 likened QE to "pouring water into a leaky bucket", noting:

In the modern financial economy, the main effect of $\mathrm{QE}$ is to boost asset prices, as market gyrations of recent weeks have clearly illustrated. But is the pursuit of higher asset prices an effective or desirable means of promoting economic growth? The distributional impact of the policy demands attention; the one certain consequence of boosting asset prices is that those with assets benefit relative to those without. Many people own houses - but, although in the UK, for example, we need more houses, we do not need another housing boom. The public also holds financial assets indirectly, largely through pension funds. But here there has been a paradoxical effect: because of the way pension funds are valued, $\mathrm{QE}$ has generally increased pension funds' liabilities more than their assets. ${ }^{17}$

The initial QE programme was halted at the end of 2013 as Britain's growth had picked up, leaving $£ 375$ billion in assets on the Bank of England's books. In the wake of the Brexit vote, however, and despite the flaws of $\mathrm{QE}$, the Bank announced a new round of bond 
purchases in August 2016. Its intention is to buy up another $£ 60$ billion in government bonds, and also for the first time to buy $£ 10$ billion in corporate bonds.

Turning to the third major dimension of how the authorities have intervened since the crisis, we have already seen in the previous section that they provided massive support to the banks - including through nationalisation - during the middle of the market meltdown in 2008. Thereafter, successive UK governments have largely relied on reregulation in dealing with the malfunctioning of banking and finance. This has involved a number of measures to strengthen public oversight of the sector and to provide a stronger regulatory framework in line with international efforts to regain some control over banking and finance. Three Financial Services Acts were passed in 2010, 2012 and 2013. The first two enhanced the functions of the Bank of England by explicitly introducing the pursuit of financial stability as an objective of public policy (the 2010 Act), and by returning regulation back to the Bank, under the auspices of its new Financial Conduct Committee (FPC) and the Prudential Regulation Authority (PRA) (the 2012 Act). ${ }^{18}$ Accompanying these institutional changes, Britain has raised capital reserve ratios which banks must have, in line with international commitments made with the G20 forum set up after the crisis and the specific requirements set out in the Basel III accords. Other measures include carrying out regular "stress tests" of all large, so-called "systemically important banks", to assess their capacity of meeting adverse market circumstances, and requiring banks to formulate "living wills" which set out how assets are sold off and how investors' money is "bailed-in" in case of bankruptcy, thus avoiding recourse to renewed taxpayer bail-outs, etc.

Apart from this, the Coalition government also launched a process of "ring-fencing" retail banking activities from investment banking activities: in other words protecting those banking activities essential to households and small businesses from the risks associated with the more speculative activities of investment banking. This was a key proposal put forward by the Independent Commission on Banking in September 2011, set up by the coalition government. It was subsequently legislated in the third Financial Services (Banking Reform) Act of 2013, and banks are expected to implement such ring-fencing by 2019. ${ }^{19}$ The policy however continues to be controversial and banks are still seeking to resist it.

This is not the place, nor is it within the author's competence, to assess the effectiveness of the process of re-regulation. However, a number of criticisms of the re-regulatory process have been much discussed. These include the relatively limited new capital reserves set out by the Basel III accords. In the baseline framework, banks are required to have equity capital (i.e. essentially the difference in the value of a bank's assets and liabilities) equivalent to $8.5 \%$ of so-called risk-weighted assets (RWAs, i.e. various types of assets banks hold that are judged to carry different levels of risks). On top of this, systemically important banks (i.e. banks' whose failure carries risks to the banking system as a whole) will be required by the Bank of England to set aside a further $3 \%$ in equity capital as a "systemic risk buffer". Taken together, however, these reserve ratios have still been judged as inadequate by Sir John Vickers, who chaired the Independent Commission on Banking (ICB) which called for retail banks to have a "primary loss absorbing capacity of at least $17 \%$ and $20 \% "{ }^{20}$ In defence of its equity capital reserve requirements, the Bank of England has argued that its regulation is better, and that its moves to push ahead with "ring-fencing" retail banking from investment will make the retail banking sector securer. ${ }^{21}$ 

to re-regulate banking, while little has been done to change how the banks and financial markets operate. In the words of (Lord) Mervyn King, a professional economist and former Governor of the Bank of England (2003-2013), in his important new book, The End of Alchemy:

The strange thing is that after arguably the biggest financial crisis in history, nothing much has really changed in terms either of the fundamental structure of banking or the reliance on central banks to restore macroeconomic prosperity. Real interest rates have fallen further. Capital has continued to flow "uphill" [from developing to developed countries]. Industrialised economies have struggled to recover. Output, even if growing slowly, is well below the pre-crisis path. Real wages have continued to stagnate. The same banks dominate Main Street and the high streets of our towns. There has certainly been a vast effort to change the regulation of banks [...]. But [initiatives in the US, the UK and in Europe] have not changed the fundamental structure of banking. ${ }^{22}$

\section{Some "heterodox" elements in explaining the crisis}

The depth and extent of the financial crisis and the Great Recession, along with the continuing difficulties of the UK economy to return to "normal", present a fundamental challenge to the neoliberal economic regime which was progressively constructed from the late 1970s onwards, based on the primacy of monetary policy, combined with reduced state intervention in the economy and market liberalisation. Arguably, the present crisis is a mirror image of the crisis of 1970s, which saw the breakdown of the Fordist, Keynesian economic regime. Mainstream or orthodox economics traditionally has difficulties in interpreting such historical changes, because of the inherent view that markets return to equilibrium, that economies eventually return to growth and that economic phenomenon do not essentially change over time. This section is therefore an attempt at providing some "heterodox" elements in explaining the persistence of the current crisis.

An obvious starting point in such an approach can be found in French Regulation theory, which emerged during the mid-1970s as an explanation of the crisis of Fordism in the United States. ${ }^{23}$ Drawing on Keynesianism and Marxism, regulation theory viewed Fordist production and the more general Fordist economy and its capital "accumulation regime" as being based on a historical compromise between capital and labour: in exchange for stable work and high wages, labour conceded to capital/management the right to organise the means of production. While it has been argued that Fordism did not develop so successfully in Britain after World War II, as reflected in the UK's relatively poor economic performance during the 1950s and 1960s, a broad political and economic compromise did exist, in what was later called the "post-war consensus". This was grounded in Keynesian policies to ensure high employment, the welfare state to provide social insurance, health care and education, as well as public ownership of a significant share of productive capital, in order to manage the economy more efficiently and more in the public interest. And it was this consensus, of course, which Mrs Thatcher and the "New Right" very explicitly set out to demolish. 

which specifically sought to strengthen market forces, enhance the power of management and capital, while reducing the power of unions and labour. On entering office in May 1979, Mrs Thatcher quickly made clear that the era of social dialogue in the UK - colloquially and pejoratively known as "beer and sandwiches in Downing Street" was over. The monetarist policies her first government (1979-1983) adopted played a significant role in the deep recession of the early 1980s and the ensuing explosion of unemployment. The privatisation of industrial companies and utilities during the $1980 \mathrm{~s}$ was a significant factor in reducing the power of unions, as were the progressive implementation of tougher anti-union laws and successive industrial disputes which Mrs Thatcher's governments won: for example, the steel industry strike in 1980, repeated public service strikes and the historical miners' strike in 1984-5 which broke this vanguard union of the British labour movement. A second, deep recession in the early 1990s, again aggravated by the monetary policy decision to enter the exchange rate mechanism (of the European Monetary System) in September 1990, contributed to a renewed surge in unemployment and a reduction in inflation, notably by breaking labour's remaining capacity to obtain higher wage claims. At the same time, income inequalities in Britain rose strongly during the 1980s, as a result of many factors including: economic restructuring, which entailed the loss of better-paid industrial jobs: relatively poorer welfare, pension and unemployment benefits; and very significant tax cuts for high income earners.

In short, British capitalism became far more confrontational rather than consensual as in the post-war era. Industrial conflicts during the 1980s were especially bitter, and led to the destruction of industrial and mining communities. Moreover, the 1980s also saw income inequalities rise strongly, although income inequality has remained fairly stable since, leaving aside the growing detachment from society of the top "1\%". More important still perhaps is the question of rising wealth inequalities. Data collection concerning wealth is far more difficult to come by, yet historically wealth tends to be much more concentrated than income, and this too is a situation which has been worsened by neoliberalism as asset prices often rise more quickly than wages, and as real interest rates earned by capital $(r)$ exceed the growth rate $(g)$. Indeed, in his landmark study of capitalism, the French economist Thomas Piketty has put forward the very simple, yet explosive notion that generally speaking $r>g$ in capitalist economies. This means that over time wealth necessarily concentrates and inequality rises. Moreover, Piketty argues that this is especially so in low-growth economies. ${ }^{24}$

The adoption of neoliberal policies from the 1980s onwards, and the move away from more the collective organisation of British society and the economy have in many ways therefore constituted a break with the historical tendency of individual rights to develop, as for example described in the renowned essay by T.H. Marshall, Citizenship and Social Class, published in 1950 as the post-war Labour government's construction of the welfare state was nearing completion. ${ }^{25}$ Marshall was echoing the "Whig view of history", that society progresses towards greater justice. He argued that individual rights advanced first from civil rights, then to political rights and lastly to social rights. In many ways, this linear progression of society can indeed be identified in the development of political rights during the $19^{\text {th }}$ century. This was followed by the emergence of social rights, as government extended its involvement in society and the economy from: Lloyd George's People's Budget in 1909; through to the creation of the NHS and a national pension scheme

Revue Française de Civilisation Britannique, XXI-2 | 2016 
during the late 1940s; on to the expansion of welfare in the 1960s; and even to the development of State Earnings-Related Pensions (SERPS) in the 1970s.

The break with increasing social democracy which Britain underwent with Thatcherism and the more confrontational relationship between capital and labour can also be analysed in more Marxist terms. While class struggle and the inherently crisis prone nature of capitalism appeared to be confined to history during the long post-war boom, the strengthening of market forces under neoliberalism has given a new relevance to Marx's analysis of capitalism. The transformative and destructive power of capitalism described in the first part of the Communist Manifesto, for example, chimes well with the advance of globalisation today. So too does the observation that capitalism - commodity production - breaks up all existing social ties by reducing relationships to "cash payments". Significantly also, the financial crisis and Great Recession have once again exposed the way capitalism and market forces are unstable, and not self-correcting as is assumed in orthodox economics. Markets do not necessarily return to equilibrium, capital is not necessarily invested rationally and financial crises are not one-off events or "acts of God". Instead they are integral to liberalised financial markets, just as capitalism manifested a historical tendency to demand deficiency prior to the emergence of the post-war Fordist, Keynesian era.

The rise in inequalities is therefore not just a social and political problem. It is also a growing economic problem, because of its impact on household demand. This is increasingly recognised by mainstream economists and even within international institutions such as the IMF and the OECD. Very specifically, in its Employment Outlook 2012, the OECD noted that the share of GDP going to wages has been declining over the last twenty years, and sometimes more: "[ $t$ ]he median labour share [in total national income] dropped to $61.7 \%$ in the late 2000s, from $66.1 \%$ in the early 1990s": in the UK, the share fell from 73.1\% of national income in 1990 to $69.0 \%$ in 2009. Moreover the OECD notes that for member countries as a whole:

Despite rising employment at the bottom end of the skill ladder, the wage share of the lowest educated slumped. This suggests that the position of certain workers, notably the least educated, in the income distribution worsened over the period. To the extent that less wealthy people tend to have a higher consumption propensity, the worsening of their labour income share might have an adverse effect on the level of aggregate demand and on how quickly economies can recover from the recent crisis. ${ }^{26}$

The question of demand deficiency is part of today's mainstream economics, even if actual Keynesian demand management was specifically rejected with the shift to monetarism in the 1970s and 1980s. The response of most governments in the industrialised countries during the initial phase of the Great Recession was therefore to support demand, as the Labour government did, for example, by cutting VAT. But since the Coalition took office in 2010, policy has been reoriented as we have seen. Moreover, the connection established in the above quote between low wages of less qualified workers and poor demand is rarely made by politicians and especially politicians on the Right, because it challenges the orthodoxy which is largely based on the idea that freer labour markets help support employment, whereas higher wages price workers out of jobs. From a Marxist point of view, however, the tendency for capital to drive down wages where possible (in order to raise surplus value and profits) is the very essence of capitalism. Also, lack of demand in the face of over-production is a clear characteristic of 
capitalism in Marx's work. As capital accumulates, profits rates must fall as the share of surplus value - labour value which goes to the capitalist in the process of production diminishes in relationship to the accumulated capital invested in production. So capitalists seek to drive down wages in order to extract more surplus value in the production process, often benefiting from a reserve of unemployed labour to hold down wages.$^{27}$ Capital also seeks to draw new categories of workers into the labour market, like women and children in the $19^{\text {th }}$ century, or migrant labour today and/or locating production outside the industrialised world where labour is abundant and cheap. Indeed, in his book Historical Capitalism, the American Marxist sociologist Immanuel Wallerstein argues that capitalism seeks to expand internationally not just to acquire markets, but actually to bring new labour into the market economy. ${ }^{28}$ Lower wages, however, result in under-consumption and hence overproduction. Such overproduction in turn is a key factor in the instability of capitalism and explains why capitalism is prone to periodic crises. During such crises, unprofitable capital is destroyed, leading to a reorganisation and concentration of capital so that profits can be restored.

Crises may also emerge in the financial sphere. Marx essentially believed that industrial capitalism would subordinate older forms of capitalism like financial capitalism, which dates back to Renaissance Italy. ${ }^{29}$ But he also pointed to the financial sector as a source of crisis, through its generation of so-called "fictitious capital". In the industrial sector, capitalists use money to buy commodities (material inputs and labour power). These are used to produce other commodities, and because this output includes a quantity of labour which is greater than the labour embodied in the inputs, more value is created and the resulting commodities are sold to obtain more money than was initially invested. In the financial sector however, investors expect to earn more money than their initial investment. But in this case, nothing real is actually produced directly, and no extra labour value is embodied in output: the increase in capital obtained by the investor is essentially fictitious. The process becomes a source of crisis when investors expect compound interest rates which are greater than the rise in real output. As times goes by, the fictitious nature of the financial investments grows, until a point is reached at which it is clear that the real resources generated in the economy cannot meet the paper value of financial assets. At this point, the market price of such assets collapses. ${ }^{30}$

Care must be taken in exaggerating the hardness of Marx's "laws" of economics (or indeed any "laws" of economics), let alone the historical inevitability of the collapse of capitalism. In his major study of capitalism's tendency to generate wealth inequality, Thomas Piketty, to take one recent example, notes that Marx underestimated the ability of capitalism to regenerate itself and in particular its ability to foster technological progress, which helps overcome the problems of accumulation, the declining profit rate and economic concentration. ${ }^{31}$ More generally, of course, the scientific nature of Marx's work and Marxism as a whole was profoundly challenged by $20^{\text {th }}$ century liberals, in particular Karl Popper. But the financial crisis and the Great Recession have also clearly revealed the fragility of the economic models which were constructed on the basis of the critique of government action and Keynesianism put forward by Hayek and Friedman. The financial crisis clearly showed that market self-regulation may fail. It highlighted the way markets are fundamentally dependent on government, and it also revealed how poorly the price mechanism may function in determining the value of assets. The profound divisions exposed in British society by the Brexit vote also confirm the way neoliberalism and the intense marketisation of society it has entailed in the UK have 
fractured society, to the extent that the question of Scottish independence continues to be a burning issue. There is therefore every justification to look beyond mainstream economics in seeking to understand the profound and protracted crisis facing the world economy in general and the UK economy in particular.

\section{Conclusion}

37 The 2007-2008 financial crisis led to massive government intervention in global markets and national banking systems. For all the subsequent - often substantial - regulation which governments have imposed on finance since, the overall policy approach has been very much based on returning to business as usual. The political agenda of the Conservatives before the Brexit referendum was emblematic of this approach: it remains to be seen to what extent their policies may now change.

Unless there is such a change, which needs to be quite radical, the fundamental problems of neoliberalism revealed by the financial crisis will persist. This view is based on more heterodox interpretations of neoliberalism and the crisis, including some of the key ideas of Marxist economics in explaining the contradictory nature of capitalism and how capitalism is prone to crises. Broadly speaking, such an analysis of capitalism and how markets work falls outside mainstream economics, which fundamentally assumes that markets do return to equilibrium and that economies ultimately return to growth. If policies do not change however, especially in the financial sector, then there are strong risks that future financial crises may occur, even greater than the last. As long ago as March 2013, for example, David Stockman, President Reagan's first budget director, published an alarming op-ed article in The New York Times warning very clearly about the unsustainable pile-up of debt in the US and global economy, and concluding that "[w]hen the latest bubble pops, there will be nothing to stop the collapse". ${ }^{32}$ More recently, on $13^{\text {th }}$ June 2015, the Economist ran a cover page showing a somewhat surprised, puny knight looking back at a dragon he had just slain named "the financial crisis", and walking unknowingly into... the jaws of a far bigger dragon. The cover headline ran: "Watch Out: The world is not ready for the next recession". It is not for nothing therefore that central bankers, policymakers and other "experts" have been fretting about the consequences of Brexit.

(This text was first completed in October 2015 and amended in August 2016.) 


\section{Table: Key Economic Indicators}

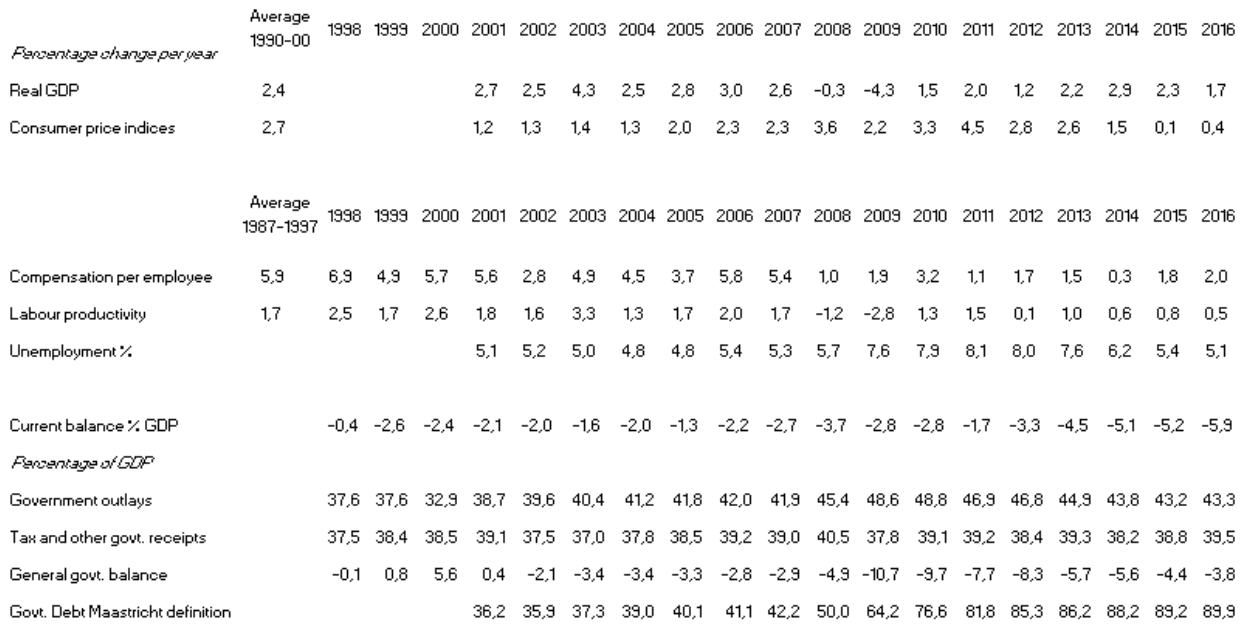

Source: OECD, Economic Outlook, No 99, Statistical Annex. June 2016.

\section{BIBLIOGRAPHY}

Aglietta Michel's, Régulation et crises de capitalisme (Paris, Odile Jacob, 1997 [1976])

Alessandri Piergiorgio and Haldane, Andrew, Banking on the State. Speech (Bank of England, $6^{\text {th }}$ November 2009).

Dar Aliyah, Economic Indicators October 2015 (House of Commons Library, Briefing Paper No 7320, 5

th October 2015).

Drezner Daniel, The System Worked: How the World Stopped another Great Depression (New York, Oxford University Press, 2014).

Greenspan Alan, Home Mortgage Market. Remarks at the annual convention of the Independent Community Bankers of America, Orlando, Florida (via satellite), $4^{\text {th }}$ March 2003.

Greenspan Alan, The mortgage market and consumer debt. Remarks at America's Community Bankers Annual Convention, Washington, D.C., $19^{\text {th }}$ October 2004.

HM Treasury, "Facing global challenges: Supporting people through difficult times", Pre-Budget Report (Cm 7484, November 2008).

House of Commons Library, Economic Indicators: E1 Trade (No 02815, 30 ${ }^{\text {th }}$ September 2015).

House of Commons Library, Productivity in the UK, website summary (6 $6^{\text {th }}$ October 2015), <http:// researchbriefings.parliament.uk/ResearchBriefing/Summary/SN06492>, [11 ${ }^{\text {th }}$ October 2015].

Hudson Michael, "From Marx to Goldman Sachs: The Fictions of Fictitious Capital and the Financialisation of Industry", Critique, Vol 38, No 3 (August 2010), pp. 419-444. 
Independent Commission on Banking (also known as the "Vickers Commission"), Final Report: Recommendations (September 2009).

Kay John, "Quantitative easing and the curious case of the leaky bucket", The Financial Times, $9^{\text {th }}$ July 2013.

King Mervyn, The End of Alchemy : Money, Banking and the Future of the Global Economy (London, Little Brown, 2016) pp 40-41.

Marshall Thomas H., Citizenship and Social Class and other essays (Cambridge, CUP, 1950).

Marx, Karl, Capital: a Critique of Political Economy, Volume 3, (1894), <https://www.marxists.org/ archive/marx/works/download/pdf/Capital-Volume-III.pdf>, [31 August 2016].

National Commission on the Causes of the Financial Crisis in the United States, Financial Crisis Inquiry Report (2011), <http://www.gpo.gov/fdsys/pkg/GPO-FCIC/pdf/GPO-FCIC.pdf>, [12 ${ }^{\text {th }}$ October 2015].

OECD, Employment Outlook 2012, Paris, OECD, 2012,

OECD, Economic Outlook, No 99, Statistical Annex (1 June 2016).

Piketty Thomas, Capital au XXIe siècle (Paris, Éditions du Seuil, 2013).

Rajan Raghuram, Fault Lines: How Hidden Fractures Still Threaten the World Economy (Princeton and Oxford, Princeton University Press, 2010).

Reinhart Carmen and Rogoff Kenneth, "The Aftermath of Financial Crises”, communication presented at the meeting of the American Economic Association in San Francisco (Saturday, $1^{\text {st }}$ March 2009).

Reinhart Carmen and Rogoff Kenneth, "Debt and Growth Revisited”, VOX (11 August 2010), <http://www.voxeu.org/article/debt-and-growth-revisited>, [12 ${ }^{\text {th }}$ October 2015].

Roubini Nouriel and Mihm Stephen, Crisis Economics: a Crash Course in the Future of Finance, (London, Penguin Books, 2011).

Stiglitz Joseph, Freefall (London, Penguin, 2009).

Stockman David, "State-Wrecked: The Corruption of Capitalism in America”, The New York Times, $30^{\text {th }}$ March 2013.

Taylor Russell, Debate on 20 March: the Level of Employment in the United Kingdom (House of Lords Library Note, LLN 2014/11, $17^{\text {th }}$ March 2014).

UK Financial Investments Ltd, An introduction: who we are, what we do, and the framework document which governs the relationship between UKFI and HM Treasury (2009), <http://www.ukfi.co.uk/ releases/UKFI\%20Introduction.pdf>, [8 ${ }^{\text {th }}$ October 2015].

Vickers John, "The Bank of England must thing again on systemic risk", The Financial Times, $14^{\text {th }}$ February 2016.

Wallerstein Immanuel, Le capitalisme historique, trans. Tutin Christian and Steiner Philippe (Paris,

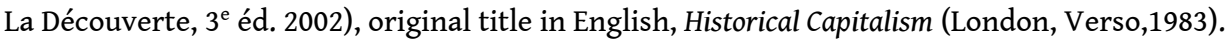

Wolf Martin, The Shifts and Shocks: What we've learned - and have still to learn - from the financial crisis (London, Allen Lane, Penguin, 2014). 


\section{NOTES}

1. WoLf Martin, The Shifts and Shocks: What We've Learned - and have still to learn - from the financial crisis (London, Allen Lane, Penguin, 2014), p. xvi.

2. "I exaggerate only a bit when I say I felt like an early Christian who had wandered into a convention of half-starved lions," RAJAN Raghuram, Fault Lines: How Hidden Fractures Still Threaten the World Economy (Princeton and Oxford, Princeton University Press, 2010), p. 3.

3. See for example, GREENSPAN Alan, Home Mortgage Market. Remarks at the annual convention of the Independent Community Bankers of America, Orlando, Florida (via satellite), March 4, 2003. GREENSPAN Alan, The mortgage market and consumer debt. Remarks at America's Community Bankers Annual Convention, Washington, D.C., $19^{\text {th }}$ October 2004.

4. STIGlitz Joseph, Freefall (London, Penguin, 2009), p. 253. He was a joint winner of the Nobel prize in economics is 2001 .

5. ROUBINI Nouriel and MIHM Stephen, Crisis Economics: a Crash Course in the Future of Finance (London, Penguin Books, 2011) p 86-114.

6. UK FINANCIAL INVESTMENTS Ltd, An introduction: who we are, what we do, and the framework document which governs the relationship between UKFI and HM Treasury (2009), <http://www.ukfi.co.uk/ releases/UKFI\%20Introduction.pdf>, [8 ${ }^{\text {th }}$ October 2015].

7. TAYLOR Russell, Debate on 20 March: the Level of Employment in the United Kingdom (House of Lords Library Note, LLN 2014/11, $1^{\text {th }}$ March 2014).

8. DAR Aliyah, Economic Indicators October 2015 (House of Commons Library, Briefing Paper No 7320, $5^{\text {th }}$ October 2015), p. 16.

9. DREZNER Daniel W., The System Worked: How the World Stopped another Great Depression (New York, Oxford University Press, 2014), pp. 24-56.

10. ALESSANDRI Piergiorgio and HALDANE Andrew, Banking on the State, speech (Bank of England, $6^{\text {th }}$ November 2009).

11. NATIONAL AUDIT OFFICE, “TAXPAYER SUPPORT FOR UK BANKS: FAQS”, <HTTP:// WWW.NAO.ORG.UK/HIGHLIGHTS/TAXPAYER-SUPPORT-FOR-UK-BANKS-FAQS/>, [12 ${ }^{\mathrm{TH}}$ OCTOBER 2015].

12. HM TREASURY, "Facing global challenges: Supporting people through difficult times", PreBudget Report (Cm 7484, November 2008).

13. REINHART Carmen and ROGOFF Kenneth, "The Aftermath of Financial Crises", communication presented at the meeting of the American Economic Association in San Francisco (Saturday, $1^{\text {st }}$ March 2009).

14. REINHART Carmen and ROGOFF Kenneth "Debt and Growth Revisited", VOX (11 ${ }^{\text {th }}$ August 2010), $<$ http://www.voxeu.org/article/debt-and-growth-revisited>, [12 ${ }^{\text {th }}$ October 2015].

15. The bank rate is the interest rate the Bank of England charges banks when they borrow overnight to meet their reserve requirements at the end of the trading day.

16. The fall in the interest rate paid by bonds is automatic as regular "coupon" payments on bonds are usually a fixed absolute amount, so that when their price rises, the coupon payments automatically fall as a relative share of the bond value.

17. KAY John, "Quantitative easing and the curious case of the leaky bucket", The Financial Times, 9 th July 2013.

18. EDMONDS Timothy, Five years of bank reform (House of Commons Library, Research Paper 15/3, $17^{\text {th }}$ March 2015). 
19. INDEPENDENT COMMISSION ON BANKING (also known as the "Vickers Commission"), Final Report: Recommendations (September 2009).

20. Ibid, p 13.

21. VICKERS John, "The Bank of England must thing again on systemic risk", The Financial Times, 14 th February 2016.

22. KING Mervyn, The End of Alchemy: Money, Banking and the Future of the Global Economy (London, Little Brown, 2016), pp 40-41.

23. The seminal reference is AGLIETTA Michel's, Régulation et crises de capitalisme (Paris, Odile Jacob, 1997 [1976]).

24. PIKETTY Thomas, Capital au XXIe siècle (Paris, Éditions du Seuil, 2013), pp 53-57.

25. MARShall Thomas H., Citizenship and Social Class and other essays (Cambridge, CUP, 1950).

26. Ibid.

27. MARX, K, Capital, Volume 3, Chapter 13, "The Las As Such", and Chapter 14 "Counteracting Influences" (1894), <https://www.marxists.org/archive/marx/works/download/pdf/CapitalVolume-III.pdf>, [31 August 2016]. .

28. WALLERSTEIN Immanuel, Le capitalisme historique, trans. TUTIN Christian and STEINER Philippe (Paris, La Découverte, $3^{\mathrm{e}}$ éd. 2002), original title in English, Historical Capitalism (London, Verso,1983).

29. HUdSON Michael, "From Marx to Goldman Sachs: The Fictions of Fictitious Capital and the Financialisation of Industry", Critique, Vol 38, No 3 (August 2010), pp. 419-444.

30. MARX, K, ibid, Chapter 25, "Credit and Fictitious Capital".

31. PIKETTY Thomas, ibid, p. 28.

32. The article was written to accompany the release of a book, and it sets out the case that since the end of the Bretton Woods gold standard the US authorities have completely corrupted the value of money and the functioning of the economy. STоскMAN David, "State-Wrecked: The Corruption of Capitalism in America", The New York Times, 30 ${ }^{\text {th }}$ March 2013.

\section{ABSTRACTS}

This article starts by noting that the financial crisis of 2007-2008 was not an accident, but the result of financial liberalisation in the preceding decades which had led to periodic and increasingly violent financial crises from the 1980s onwards. The article moves on to review the increasing difficulty that policies implemented to overcome the crisis and the Great Recession have in stimulating growth today, focussing on the UK. The article proceeds by noting that neoliberalism has led to rising inequalities. As a result, the relationship between capital and labour is not only more confrontational but households are also suffering stagnant income growth, and so are constrained in contributing to aggregate demand. In some ways, it therefore appears that pressure on profits and wages is making capitalism more unstable and inherently subject to crises, as analysed by Marx during the age of $19^{\text {th }}$ century liberalism. At the same time, the greater financialisation of national and the global economies means that they are more subject to economic shocks arising from financial crises, when the "fictitious" nature of financial assets is revealed, also discussed by Marx in Capital. 
Cet article part du constat que la crise financière de 2007-2008 n'était pas un accident, mais qu'elle était la conséquence de la libéralisation financière des décennies précédentes qui a provoqué des crises financières périodiques de plus en plus violentes depuis les années 1980. Par la suite, l'article examine les difficultés de plus en plus importantes que rencontrent aujourd'hui les politiques économiques mises en œuvre en réaction à la crise et à la Grande récession pour stimuler la croissance. Une attention particulière est accordée au Royaume-Uni. L'article poursuit en notant que le néolibéralisme a aggravé les inégalités sociales, que la relation entre le capital et le travail est devenue plus conflictuelle et que l'augmentation très limitée des revenus des ménages contribue difficilement à la demande globale. On retrouve alors en quelque sorte les mêmes mécanismes qui font pression sur les profits et les salaires et que Marx a analysés à propos du libéralisme du XIXème siècle. Dans le même temps, la financiarisation des économies nationale et mondiale fait qu'elles sont plus exposées à des chocs provenant de crises financières quand la nature «fictive » des actifs financiers est révélée, ce qu'examine également Marx dans Le Capital.

\section{INDEX}

Keywords: Financial crisis, Great Recession, economic crises, economic policy, monetary policy, fiscal policy, demand deficiency, Marxism.

Mots-clés: Crise financière, Grande récession, crise économique, politique économique, politique monétaire, politique budgétaire, insuffisance de demande, marxisme.

\section{AUTHOR}

\section{NICHOLAS SOWELS}

Université Paris 1 and CREC Université Paris 3 